\title{
A sub-decadal trend in diacids in atmospheric aerosols in eastern Asia
}

\author{
S. Kundu ${ }^{1, a}$, K. Kawamura ${ }^{1}$, M. Kobayashi ${ }^{1}$, E. Tachibana ${ }^{1}$, M. Lee ${ }^{2}$, P. Q. Fu ${ }^{1,3}$, and J. Jung ${ }^{1, b}$ \\ ${ }^{1}$ Institute of Low Temperature Science, Hokkaido University, Sapporo 060-0819, Japan \\ ${ }^{2}$ Department of Earth and Environmental Science, Korea University, Seoul 136-701, South Korea \\ ${ }^{3}$ LAPC, Institute of Atmospheric Physics, Chinese Academy of Sciences, Beijing 100029, China \\ ${ }^{a}$ now at: Chemistry Department, University of Massachusetts, Amherst, MA 01003, USA \\ bnow at: Korea Research Institute of Standards and Science, Daejeon 305-340, South Korea
}

Correspondence to: S. Kundu (drkundu@umass.edu)

Received: 19 July 2015 - Published in Atmos. Chem. Phys. Discuss.: 18 August 2015

Revised: 19 December 2015 - Accepted: 22 December 2015 - Published: 19 January 2016

\begin{abstract}
Change in secondary organic aerosols (SOAs) has been predicted to be highly uncertain in the future atmosphere in Asia. To better quantify the SOA change, we examine the sub-decadal (2001-2008) trend in major surrogate compounds $\left(\mathrm{C}_{2}-\mathrm{C}_{10}\right.$ diacids) of SOA in atmospheric aerosols from Gosan site on Cheju Island, South Korea. The Gosan site is influenced by pollution outflows from eastern Asia. The molecular distributions of diacids were characterized by the predominance of oxalic $\left(\mathrm{C}_{2}\right)$ acid followed by malonic $\left(\mathrm{C}_{3}\right)$ and succinic $\left(\mathrm{C}_{4}\right)$ acids in each year. The seasonal variations in diacids in each year were characterized by the highest concentrations of saturated diacids in spring and unsaturated diacids in winter. The consistent molecular distributions and seasonal variations along with significantly similar air mass transport patterns are indicative of similar pollution sources for diacids in eastern Asia on a subdecadal scale. However, the intensity of the pollution sources has increased as evidenced by the increases in major diacids at the rate of $3.9-47.4 \%$ per year, particularly in April. The temporal variations in atmospheric tracer compounds (carbon monoxide, levoglucosan, 2-methyltetrols, pinic acid, glyoxylic acid, glyoxal and methylglyoxal) suggest that the increases in diacids are due to enhanced precursor emissions associated with more anthropogenic than biogenic activities followed by the compounds' chemical processing in the atmosphere. The trends in diacids contrast with the reported decreases in sulfate, nitrate and ammonium in recent years in eastern Asia. This study demonstrates that recent pollution control strategies in eastern Asia were not able to decrease
\end{abstract}

organic acidic species in the atmosphere. The increases in water-soluble organic acid fraction could modify the aerosol organic composition and its sensitivity to climate relevant physical properties.

\section{Introduction}

Organic carbon (OC) can account for $\sim 15-25 \%$ of aerosol mass in $\mathrm{PM}_{10}$ atmospheric particles (Boucher et al., 2013) and $\sim 10-60 \%$ of aerosol mass in non-refractory $\mathrm{PM}_{1}$ atmospheric particles (Zhang et al., 2007). These contributions are comparable to those of other major aerosol components, including dust, sulfate, nitrate and ammonium (Zhang et al., 2007; Boucher et al., 2013). Source attribution studies have estimated up to $80 \%$ of OC as secondary in atmospheric aerosols (Zhang et al., 2007; Offenberg et al., 2007; Hallquist et al., 2009; Ding et al., 2012). The budget of global secondary organic aerosols (SOAs), derived from the oxidation of volatile organic compounds (VOCs), is higher than that of global primary organic aerosols (POAs) (Hallquist et al., 2009). The SOA can modulate the water-uptake behavior of atmospheric aerosols (Swietlicki et al., 2008; Hong et al., 2014) and have adverse impacts on human health (Nawrot et al., 2007; Hallquist et al., 2009).

Although there are some primary sources of diacids with a low molecular weight and carbon numbers of 2-10 (Kawamura and Kaplan, 1987; Schauer et al., 1999, 2001), these diacids are overwhelmingly generated in the atmosphere 
(Kalberer et al., 2000; Warneck, 2003; Fisseha et al., 2004; Tedetti et al., 2007; Kundu et al., 2010a; Charbouillot et al., 2012). For example, $<1 \%$ of oxalic acid has been estimated to be emitted from primary sources, whereas the remaining part has been calculated to form in the aqueous phase from precursors (e. g., glyoxal, methylglyoxal and glyoxylic acid) derived by the oxidation of biogenic and anthropogenic VOCs (Myriokefalitakis et al., 2011). Oxalic acid, the most abundant species of the diacids, can account for as much as half of the global SOA budget (Hallquist et al., 2009; Myriokefalitakis et al., 2011). Low-molecular-weight diacids have been ubiquitously detected in atmospheric aerosols, accounting for up to $20 \%$ of the water-soluble carbonaceous fraction of atmospheric aerosols (Kawamura and Sakaguchi, 1999; Kerminen et al., 1999; Decesari et al., 2006). These contributions are higher than those of known major SOA tracers from biogenic and anthropogenic VOCs (Kleindienst et al., 2007; Stone et al., 2010; Fu et al., 2014). Thus, diacids are important surrogates of SOA in the atmosphere due to their ubiquity, secondary nature, and high contributions to SOA mass. In addition, diacids impart acidity to atmospheric aerosols (Myriokefalitakis et al., 2011). Diacids may be good indicators for evaluating the changes in SOA concentrations and their composition and physical properties in the future atmosphere.

Chemistry-transport models have predicted that the global SOA net production may change from 0.4 to $214 \%$ by the end of the 21st century compared to that in 1990-2000 (Naik et al., 2004; Liao et al., 2006; Tsigaridis and Kanakidou, 2007; Heald et al., 2008). These large uncertainties are due to those associated with the predicted climate scenarios and various components of global atmosphere-land models. For example, there are 40 SRES (Special Report on Emission Scenarios) scenarios, which have resulted in carbon dioxide emissions in the range of 3.3 to $37 \mathrm{Gt} \mathrm{C} \mathrm{yr}^{-1}$ by the end of 2100 (Nakicenovic et al., 2000), and isoprene emissions have been projected to show increases in the range of $500-1000 \mathrm{Tg}$ (Levis et al., 2003; Tao and Jain, 2005; Guenther et al., 2006). Due to a large uncertainty in the projection of SOA using the models, long-term observations of the major surrogates (e.g., diacids) of SOA are required for a better understanding of the changes in SOA in the coming years.

Due to the importance of diacids as a pool of SOA, we study their long-term (2001-2008) trends in atmospheric aerosol samples (the number of samples, $n$, is 718) collected at the Gosan site on Cheju Island, South Korea. Gosan is heavily influenced by pollution outflows from eastern Asia. Therefore, any change in the abundances of diacids will reflect the alteration of the pollution sources and atmospheric chemical processes in eastern Asia. Eastern Asia is of particular importance because chemistry-climate modeling has predicted the highest increases in SOA abundances in the future Asian atmosphere (Heald et al., 2008). A sub-decadal trend obtained from the present study could be used as a reference to evaluate the alteration of the composition and phys-

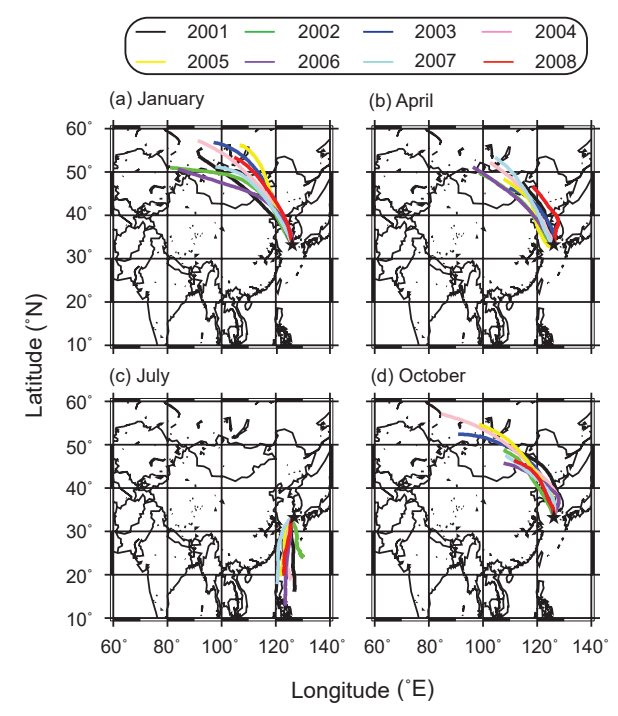

Figure 1. Map showing the Gosan site (star symbol) on Cheju Island, South Korea, along with the monthly averaged air mass backward trajectories for the time period of 2001-2008: (a) January, (b) April, (c) July and (d) October. Backward trajectories were calculated using the NOAA HYSPLIT model at $500 \mathrm{~m}$ above ground level over 5 days.

ical properties of SOA in the future atmosphere in eastern Asia.

\section{Experimental section}

\subsection{Site description}

The Gosan site on Cheju Island $\left(33^{\circ} 29^{\prime} \mathrm{N}, 126^{\circ} 16^{\prime} \mathrm{E}\right)$ is situated at the boundary of the Yellow Sea and East China Sea (Fig. 1). The site is $\sim 100 \mathrm{~km}$ south of the Korean Peninsula, $\sim 500 \mathrm{~km}$ east of China (Jiangsu province and Shanghai), $\sim 200 \mathrm{~km}$ west of Kyushu Island, Japan, and $\sim 1000 \mathrm{~km}$ northeast of Taipei. The Gosan site is located on the western edge of Cheju Island, which is isolated from residential areas on the island, and the surroundings are covered with grasses (Kundu et al., 2010c). Due to its location and very limited local anthropogenic emissions, Gosan has been considered as an ideal site to monitor the outflows from eastern Asia (Kundu et al., 2010c).

\subsection{Aerosol sampling}

Atmospheric total suspended particle (TSP) samples $(n=$ 714) were collected at Gosan over $6 \mathrm{~h}$ to 7 days throughout the year from April 2001 to November 2008. The total number of samples collected was 71 in 2001, 25 in 2002, 48 in 2003, 98 in 2004, 123 in 2005, 116 in 2006, 142 in 2007, and 91 in 2008. Due to various technical problems, aerosol samples could not be collected in January-March 2001; AprilDecember 2002; January-March 2003; July-August 2005; 
September-October 2006; and May and December 2008. Aerosol samples were collected on precombusted $\left(500^{\circ} \mathrm{C}\right)$ quartz fiber filters $(20 \times 25 \mathrm{~cm}$, Pallflex 2500 QAT-UP $)$ using a high-volume air sampler (Kimoto AS-810) installed on the roof of a trailer house ( $\sim 3 \mathrm{~m}$ above the ground). The flow rate was maintained at $0.8 \mathrm{~m}^{-3} \mathrm{~min}^{-1}$. Prebaked glass jars $(150 \mathrm{~mL})$ with a Teflon-lined screw cap were used to store the filters before and after the sampling. Samples were kept in a freezer after the collection, transported to our laboratory at ambient temperatures, and then kept in a dark freezer room again at $-20^{\circ} \mathrm{C}$ until analysis. Field blank filters were collected periodically by setting the filter substrates on the filter cartridge at Gosan; however, air was not passed through the filter.

\subsection{Analytical method}

Aerosol samples were analyzed for diacids $\left(\mathrm{C}_{2}-\mathrm{C}_{10}\right)$, oxoacid (glyoxylic acid) and $\alpha$-dicarbonyls (glyoxal and methylglyoxal) using a method described elsewhere (Kawamura, 1993). Briefly, target analytes were isolated by the extraction of aliquots of filter samples with water $(5 \mathrm{~mL} \times 3$, $>18 \mathrm{M} \Omega$ ) under ultrasonic agitation. The aerosol extract was filtered to remove filter debris and insoluble particles using a glass column (Pasteur pipette) packed with quartz wool. Aerosol extracts were evaporated to almost dryness using a rotary evaporator $\left(\sim 40^{\circ} \mathrm{C}\right)$ under vacuum. The target analytes then were derivatized with $14 \%$ boron trifluoride in nbutanol at $100^{\circ} \mathrm{C}$ for over $1 \mathrm{~h}$. Water and hexane were simultaneously added to isolate derivatized esters and acetals from polar compounds. Esters and acetals partitioned into nhexane, whereas inorganic materials such as boric and fluoric acids were dissolved in water. The hexane layer was separated and completely dried using a rotary evaporator under vacuum and the nitrogen $\left(\mathrm{N}_{2}\right)$ blow-down technique. Then, the esters and acetals of target analytes were dissolved in a known volume of n-hexane.

A $2 \mu \mathrm{L}$ aliquot of the sample was injected into a capillary gas chromatograph (GC, Hewlett-Packard, HP6890) equipped with a split-splitless injector, fused silica capillary column $(\mathrm{HP}-5 ; 25 \mathrm{~m} \times 0.2 \mathrm{~mm} \times 0.5 \mu \mathrm{m}-$ length $\times$ inner diameter $\times$ film thickness) and flame ionization detector (FID). The GC oven temperature was maintained at $50^{\circ} \mathrm{C}$ for $2 \mathrm{~min}$, ramped to $120^{\circ} \mathrm{C}$ at $30^{\circ} \mathrm{C} \mathrm{min}^{-1}$, then to $310^{\circ} \mathrm{C}$ at $6^{\circ} \mathrm{C} \mathrm{min}-1$, and held there for $10 \mathrm{~min}$. Peaks on the GC chromatograms were identified with reference to the authentic standard retention times obtained by GC-FID and mass spectra acquired using a mass spectrometer (MS) (Thermoquest, Trace MS). The concentrations were calculated in terms of the peak area of authentic dibutyl succinate.

Free diacids were spiked onto precombusted quartz fiber filters and analyzed like the actual samples to test the recovery. The recoveries were found to be $80-85 \%$ for oxalic acid and above $90 \%$ for malonic, glutaric, succinic, and adipic acids. The recoveries of glyoxylic acid, glyoxal, and methyl- glyoxal have been reported to be 88,91 and $47 \%$, respectively (Kawamura et al., 2013). Replicate analyses of aerosol samples showed that the analytical error of this method was less than $10 \%$ for major species reported in this study. Field blanks showed small peaks of oxalic, succinic, adipic, and phthalic acids and methylglyoxal. However, their levels were very low $(0.1-3 \%)$ compared to those of the real samples. The reported concentrations have been corrected for the field blanks but not for recoveries.

Levoglucosan (a biomass burning tracer), 2-methyltetrols (isoprene-derived SOA tracers) and pinic acid ( $\alpha$-pinenederived SOA tracer) were determined in aerosol samples collected from 2003 to 2004 using a GC-MS instrument. The detailed analytical protocols have been described elsewhere (Fu et al., 2014). Total carbon (TC) was measured using an elemental analyzer (EA; model: NA 1500 NCS, Carlo Erba Instruments) for aerosol samples collected from 2001 to 2006 following the method described elsewhere (Kundu et al., 2010b). A small disc (area $2.54 \mathrm{~cm}^{2}$ ) of each filter sample was placed into a cleaned tin cup, which was closed using tweezers and then introduced into the EA using an autosampler. The samples were burned in the presence of pure oxygen in a combustion column packed with chromium trioxide at $1020^{\circ} \mathrm{C}$. The derived carbon dioxide $\left(\mathrm{CO}_{2}\right)$ was separated on a GC installed within the EA instrument and then measured with a thermal conductivity detector. The concentrations of $\mathrm{O}_{3}$ and $\mathrm{CO}$ were measured by the Korea Meteorological Administration (KMA) using Thermo environmental instruments 49C and 48C, respectively (Thermo Inc., USA).

\section{Results and discussion}

\subsection{Interannual variations in the molecular distributions of diacids}

Molecular distributions, related to the presence or absence and abundance of organic compounds in atmospheric aerosols, provide important information about the compounds' sources, formation, chemical evolution and physical properties (Hallquist et al., 2009). Lower- $\left(C_{2}-C_{6}\right)$ and higher- $\left(\mathrm{C}_{7}-\mathrm{C}_{10}\right)$ molecular-weight normal-chain diacids, branched-chain diacids $\left(\mathrm{C}_{4}-\mathrm{C}_{6}\right)$, multifunctional diacids $\left(\mathrm{C}_{3}-\mathrm{C}_{7}\right)$, and unsaturated diacids $\left(\mathrm{C}_{4}-\mathrm{C}_{8}\right)$ were detected in this study. Table 1 presents their full and abbreviated names and monthly concentrations (range and average) over the time period of 2001-2008.

The molecular distributions are discussed here based on the monthly median concentrations of the individual years. Oxalic $\left(\mathrm{C}_{2}\right)$ acid was found to be the most abundant species, followed by either malonic $\left(\mathrm{C}_{3}\right)$ acid or succinic $\left(\mathrm{C}_{4}\right)$ acid, among all detected diacids in every month of the studied years (2001-2008). The fourth, fifth and sixth most abundant diacids were highly variable with the predominance of glutaric $\left(\mathrm{C}_{5}\right)$, adipic $\left(\mathrm{C}_{6}\right)$, azelaic $\left(\mathrm{C}_{9}\right)$, malic $\left(\mathrm{hC}_{4}\right)$, terephthalic 

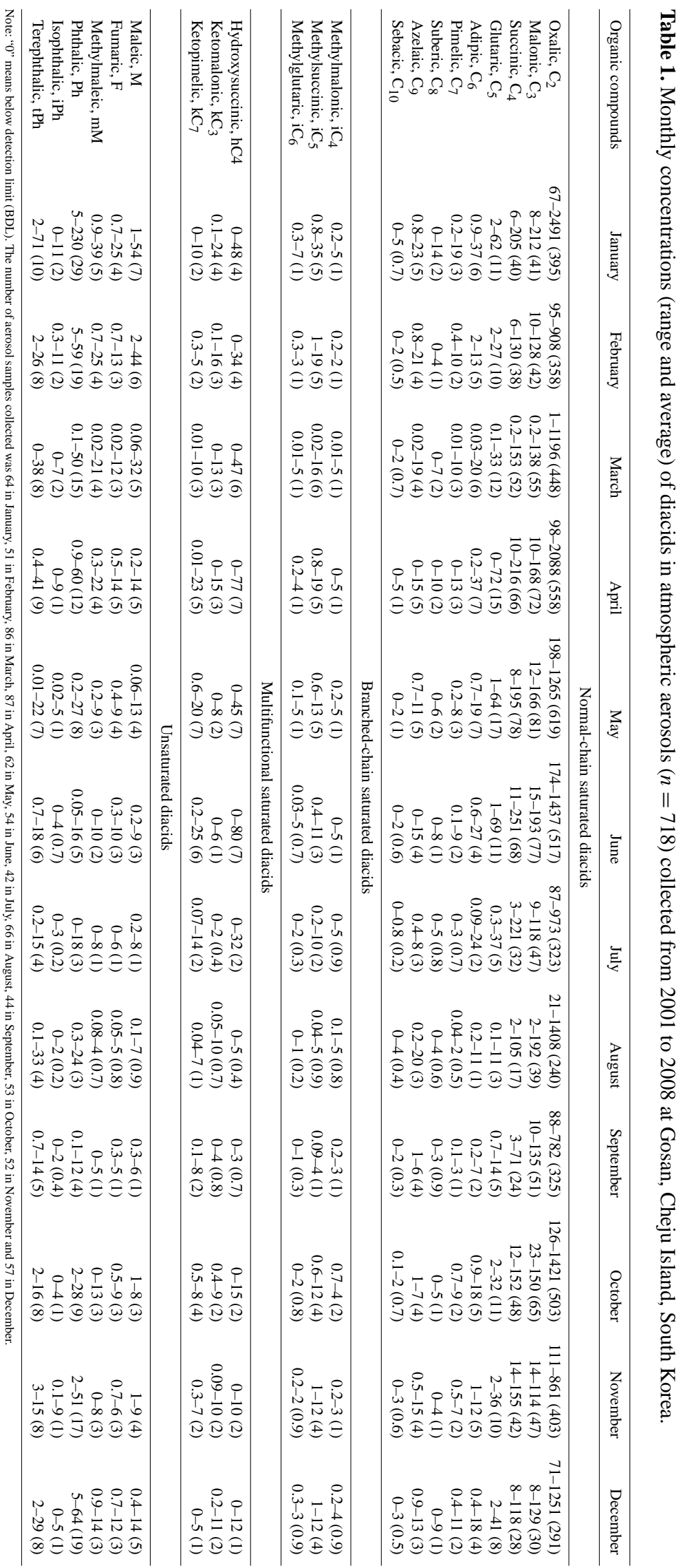

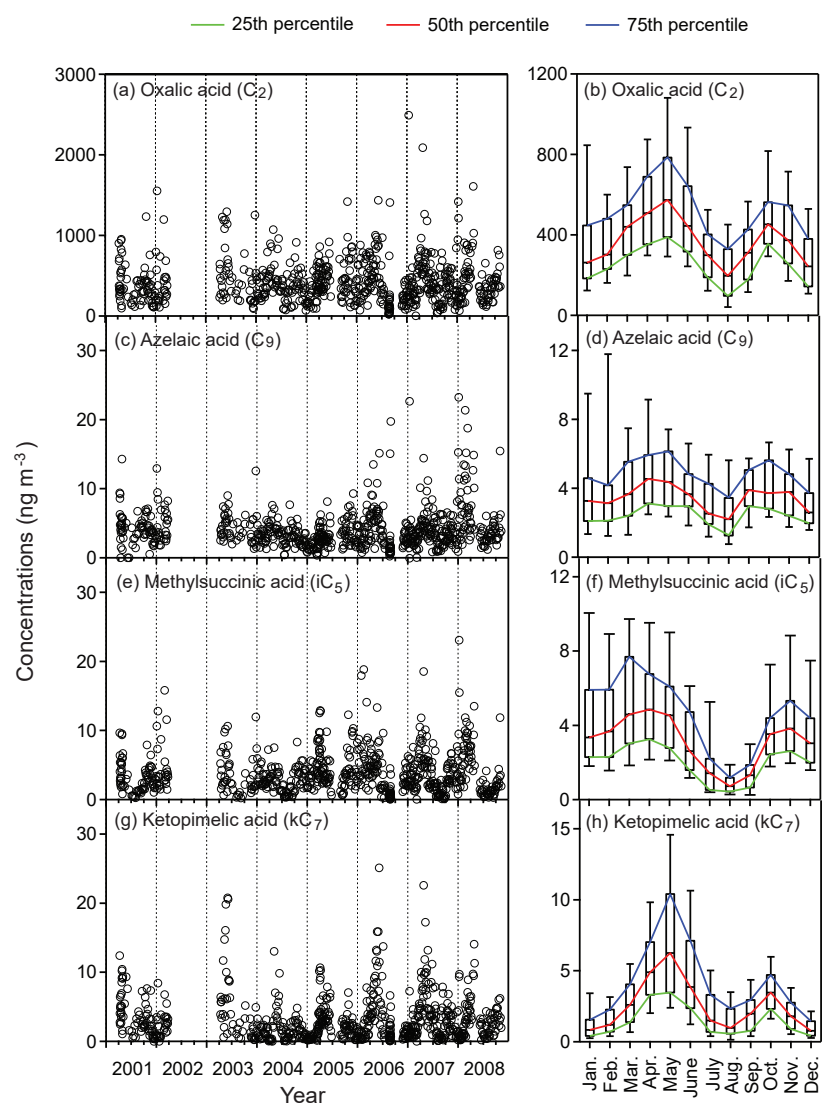

Figure 2. Seasonal variations in selected saturated and multifunctional diacids, including oxalic (a, b), azelaic (c, d), methylsuccinic $(\mathbf{e}, \mathbf{f})$ and ketopimelic $(\mathbf{g}, \mathbf{h})$ acids, in ambient aerosol samples. The right panels are drawn based on the monthly binned concentrations irrespective of the years. The lower and upper whiskers represent the 10th and 90th percentiles, respectively. The outliers are excluded in the right panels to avoid any distortion in the seasonality.

$(\mathrm{tPh})$, and phthalic $(\mathrm{Ph})$ acids. Similar types of molecular distributions have also been reported in atmospheric aerosols collected around the globe (Kawamura and Sakaguchi, 1999; Kerminen et al., 1999; Decesari et al., 2006; Kundu et al., 2010a, c; Kawamura et al., 2013). To explore interannual differences in the molecular distributions, an analysis of variance (ANOVA) was carried out by comparing the median concentrations of the similar months of 2001-2008. Significant $(p<0.05)$ differences in the molecular distributions of diacids were not observed among the studied years. Based on these results and similarity of mean air mass trajectory pathways among the identical months (exception: May, June, August and September) of 2001-2008 (as shown in Figs. 1a-d and $\mathrm{S} 1 \mathrm{a}-\mathrm{h}$ in the Supplement), we conclude that the sources of diacids mostly remain identical in eastern Asia on a subdecadal scale.
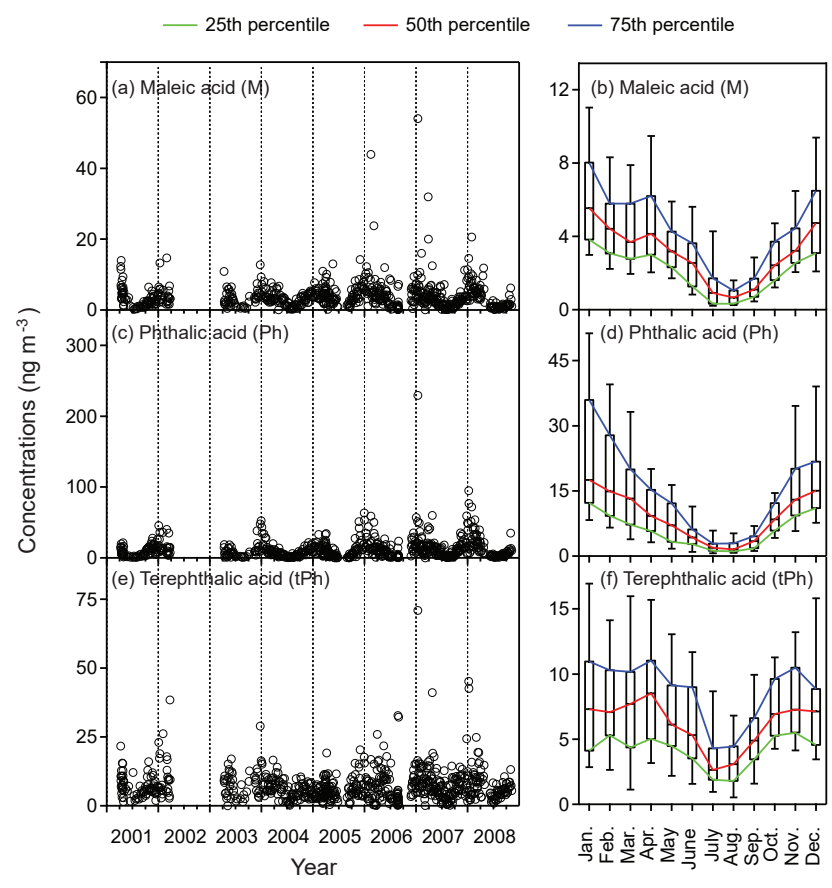

Figure 3. Seasonal variations in selected unsaturated diacids, including maleic (a, b), phthalic (c, d) and terephthalic (e, f) acids, in ambient aerosol samples. The right panels are drawn based on the monthly binned concentrations irrespective of the years. The lower and upper whiskers represent the 10th and 90th percentiles, respectively. The outliers are excluded in the right panels to avoid any distortion in the seasonality.

\subsection{Seasonal variations in diacids}

The four seasons as follows are defined in this study: March-May as spring, June-August as summer, SeptemberNovember as autumn and December-February as winter. Saturated and multifunctional diacids showed maxima in spring with comparable concentrations in autumn and winter (Figs. 2a-h and S2a-h). In contrast, unsaturated diacids, except for fumaric acid (F), showed maxima in winter (Figs. 3a-f and S3a-f). We discuss the observed seasonality in terms of air mass trajectory, primary and secondary pollution sources, meteorological parameters (boundary layer height, precipitation, temperature and humidity), and sink terms (oxidation by hydroxyl $(\mathrm{OH})$ radicals and wet deposition).

Typical air mass transport patterns at Gosan are shown with reference to the middle month of each season over the time period of 2001-2008 (Fig. 1). The air mass transport patterns for the remaining months are shown in Fig. S1. Maximum concentrations of saturated diacids in the spring months are due to polluted air mass transport to Gosan from eastern China (Fig. 1b), where the highest concentration of nitrogen dioxide $\left(\mathrm{NO}_{2}\right)$ has been identified by satellite instruments (Richter et al., 2005). High concentrations of un- 

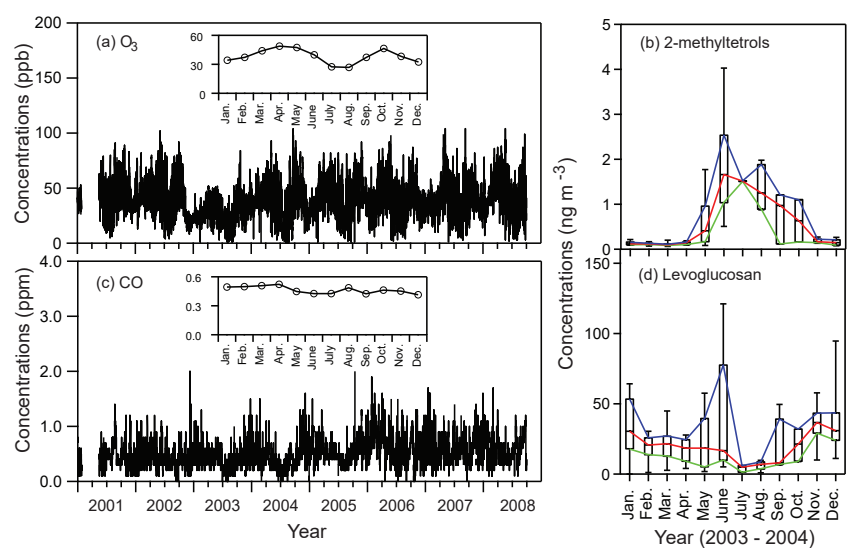

Figure 4. Seasonal variations in chemical tracers in the atmosphere at Gosan: (a) ozone $\left(\mathrm{O}_{3}\right)$, (b) 2-methyltetrols, (c) carbon monoxide (CO) and (d) levoglucosan. $\mathrm{O}_{3}$ and $\mathrm{CO}$ data were obtained from the Korea Meteorological Administration (KMA). The insets in the left panels show the monthly averaged concentrations of $\mathrm{O}_{3}$ and $\mathrm{CO}$ during the time period of 2001-2008.

saturated diacids in the cold seasons (winter and autumn) coincide with the passage of air masses from northern China (Fig. 1a, d). The consumption of coal and biomass is significantly enhanced due to the heating of homes in the cold seasons in northern China (Kundu et al., 2010a). The low concentrations for all saturated and unsaturated diacids in summer are due to the transport of marine air parcels at Gosan. The marine air parcels are delivered to the Gosan site from the China Sea, Yellow Sea and western North Pacific in summer (Fig. 1c).

The seasonal distributions of saturated diacids are different from those of unsaturated diacids, suggesting that their sources could be season-specific. The highest concentrations of saturated diacids in spring overlap with the maxima of ozone $\left(\mathrm{O}_{3}\right)$ at Gosan (Fig. 4a) and its surrounding polluted regions in eastern Asia (Naja and Akimoto, 2004; Ohara et al., 2007; Xu et al., 2008; Wang et al., 2009), indicating an elevated production of diacids by atmospheric chemical processes. Previous studies reported that diacids in SOA were generated by the oxidation of anthropogenic (e.g., cyclohexene, 1, 3, 5-trimethylbenzene) and biogenic VOCs (e.g., isoprene) (Kalberer et al., 2000; Fisseha et al., 2004; Myriokefalitakis et al., 2011). Diacids with higher abundances have also been found in biomassburning-influenced aerosols (Kundu et al., 2010a; Myriokefalitakis et al., 2011; Kawamura et al., 2013). In the spring of 2003 and of 2004, major saturated diacids did not correlate, or only loosely correlated, with 2-methyltetrols (isopreneSOA tracers, $\left.r^{2}=0.001-0.05\right)$ (Fig. 5a-e), pinic acid $(\alpha-$ pinene-SOA tracer, 0.10-0.39) (Fig. 6a-e) and levoglucosan (biomass burning tracer, 0.001-0.07) (Fig. 7a-e) (e.g., Fu et al., 2014). The lack of correlations in spring could be related with greater production of diacids from the oxidation

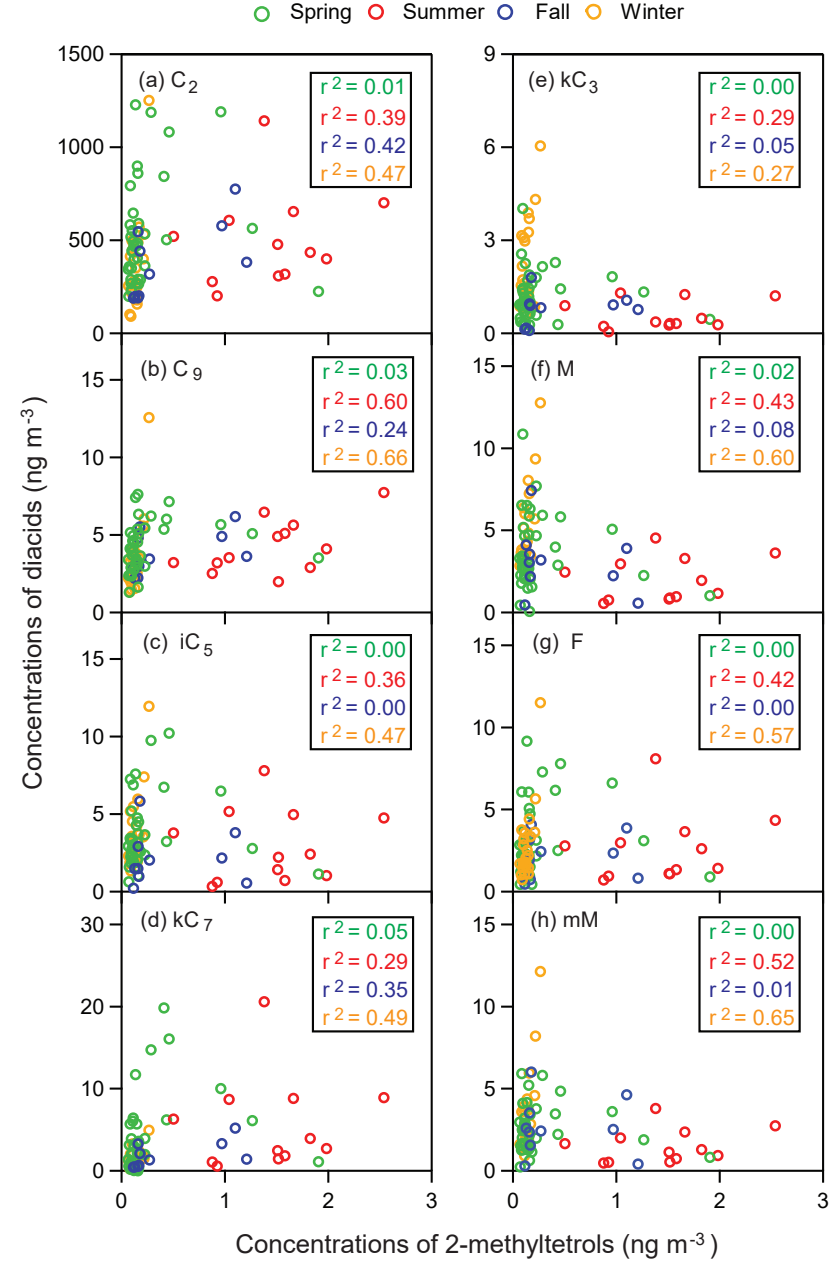

Figure 5. Correlations of 2-methyltetrols (SOA tracers of isoprene) with saturated (a-e) and unsaturated $(\mathbf{f}-\mathbf{h})$ diacids in aerosol samples collected from April 2003 to April 2004: (a) oxalic $\left(\mathrm{C}_{2}\right)$, (b) azelaic $\left(\mathrm{C}_{9}\right)$, (c) methylsuccinic $\left(\mathrm{iC}_{5}\right)$, (d) ketopimelic $\left(\mathrm{kC}_{7}\right)$, (e) ketomalonic $\left(\mathrm{kC}_{3}\right)$, (f) maleic $(\mathrm{M})$, (g) fumaric $(\mathrm{F})$ and (h) methylmaleic $(\mathrm{mM})$ acids. Note that data have been grouped according to the season.

of anthropogenic VOCs than from the oxidation of biogenic VOCs and related biomass-burning-derived precursors. This interpretation can be supported by the fact that concentrations of 2-methyltetrols and pinic acid in spring are 2.26.5 times lower than those in summer (Fig. 4b). In contrast, saturated diacids showed significant $(p<0.05)$ correlations in summer $\left(r^{2}=0.29-0.60\right)$ and winter $(0.47-0.66)$ with 2methyltetrols (Fig. 5a-e), pinic acid (0.48-0.95 and 0.300.82 , respectively) (Fig. 6a-e), and levoglucosan (0.38-0.70 and $0.35-0.72$, respectively) (Fig. 7a-e). These results show that the oxidation of biogenic VOCs and biomass-burningderived precursors are the dominant sources of diacids in summer and winter.

The seasonal variations in unsaturated diacids are similar to those of levoglucosan (biomass burning tracer) and 


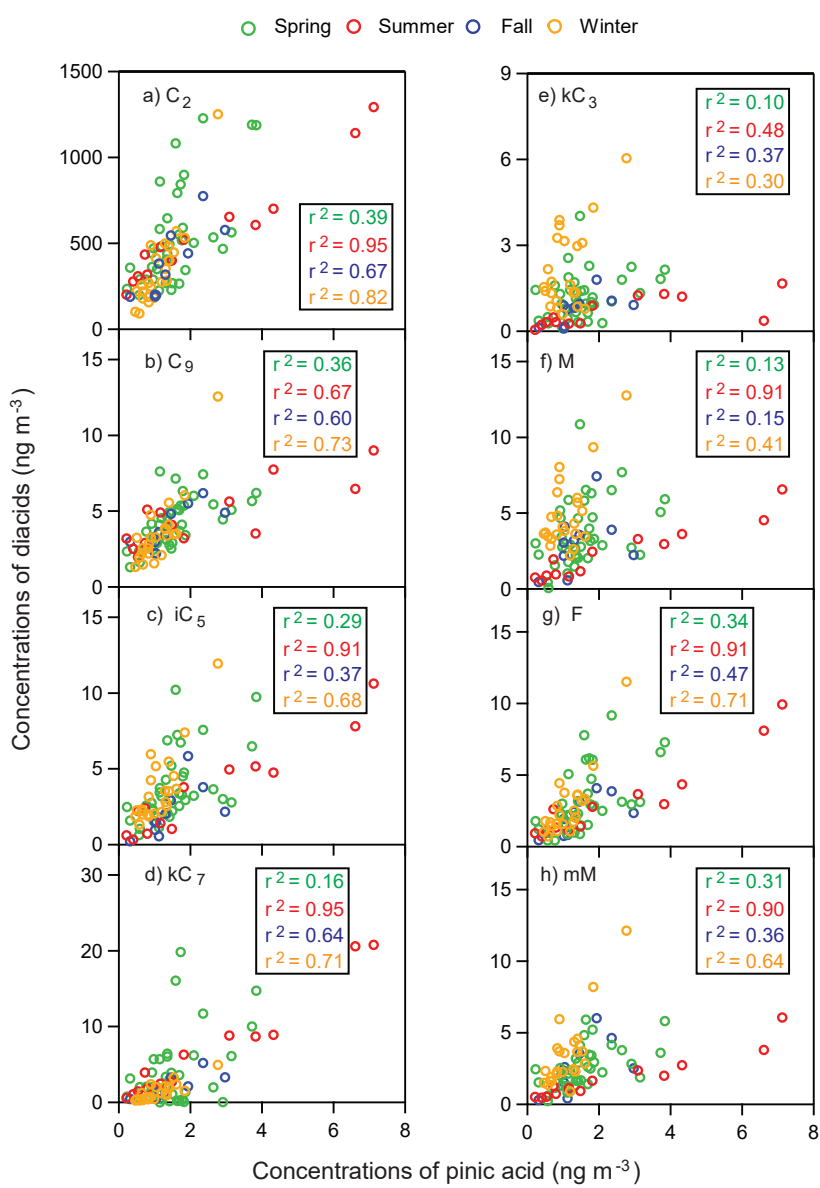

Figure 6. Correlations of pinic acid (a SOA tracer of $\alpha$-pinene) with saturated (a-e) and unsaturated (f-h) diacids in aerosol samples collected from April 2003 to April 2004: (a) oxalic $\left(\mathrm{C}_{2}\right)$, (b) azelaic $\left(\mathrm{C}_{9}\right)$, (c) methylsuccinic $\left(\mathrm{iC}_{5}\right)$, (d) ketopimelic $\left(\mathrm{kC}_{7}\right)$, (e) ketomalonic $\left(\mathrm{kC}_{3}\right)$, (f) maleic $(\mathrm{M}),(\mathrm{g})$ fumaric $(\mathrm{F})$ and $(\mathbf{h})$ methylmaleic $(\mathrm{mM})$ acids. Note that data have been grouped according to the season.

$\mathrm{CO}$ (combustion tracer) (Fig. 4c, d). Close correlations $\left(r^{2}=0.61-0.76\right)$ were obtained between the major unsaturated diacids and levoglucosan in winter at the $95 \%$ confidence level (Fig. $7 \mathrm{f}-\mathrm{g}$ ). These correlations were reduced to $0.39-0.64$ in summer and $0.42-0.54$ in autumn (Fig. 7f-g), suggesting that biomass-burning-derived precursors are the strongest sources of unsaturated diacids in winter followed by summer and fall. There are no correlations between unsaturated diacids and levoglucosan in spring, further suggesting that biomass-burning-derived precursors are not an important source of diacids in spring in eastern Asia. Aliphatic unsaturated diacids, including maleic $(\mathrm{M})$, fumaric $(\mathrm{F})$ and methylmaleic $(\mathrm{mM})$ acids, are significantly $(p<0.05)$ correlated in summer $\left(r^{2}=0.40-0.52\right)$ and winter $\left(r^{2}=0.57-0.60\right)$ with 2-methyltetrols (Fig. 5f) and pinic acid (0.90-0.91 and 0.410.71 , respectively) (Fig. 6f). These results show that there is a strong link between aliphatic unsaturated diacids and biogenic VOCs.

TC-normalized concentrations of saturated diacids showed higher values in spring and lower values in winter, like the absolute concentrations; however, a peak emerged in summer (Fig. S4a-h). These results show that the dilution of the atmosphere does not affect the spring maxima, but summer concentrations are decreased by atmospheric dilution mainly due to the transport of clean air masses from the oceans. The seasonality of TC-normalized concentrations of unsaturated diacids was characterized by winter maxima, being similar to the seasonality of their absolute concentrations in winter (Fig. S5a-f). These results indicate that a contraction of the boundary layer had no effect on the winter maxima. Aerosol liquid water content and aerosol composition are not expected to drive the seasonality of diacids as an insignificant amount ( $<5 \%$ of global budget) of oxalic acid has been estimated to be generated in aqueous aerosols (Myriokefalitakis et al., 2011).

About 62 and $34 \%$ of the global budget of oxalic acid and potentially other diacids are removed from the atmosphere by wet deposition and oxidation by $\mathrm{OH}$ radicals, respectively (Myriokefalitakis et al., 2011). Therefore, less precipitation (Fig. S6a) and lower $\mathrm{OH}$ radical concentrations in winter may have an effect on the winter maxima of unsaturated diacids. However, this effect should not be dominating over the major factors (e.g., sources and air mass transport) because of the observed peak maxima of saturated diacids in spring when a high amount of precipitation has been observed (Fig. S6a), and higher $\mathrm{OH}$ radical concentrations are expected in spring than in winter (Kanaya et al., 2007). Temperature and relative humidity showed the highest values in summer at Gosan followed by spring and the cold seasons (winter and autumn) (Fig. S6b, c); however, neither temperature nor relative humidity are expected to affect seasonality via the partitioning because of the predominance of diacids in aerosol phase (Mochida et al., 2003). In conclusion, the seasonal cycles of saturated and unsaturated diacids at Gosan are mostly likely determined by air mass pathways associated with the diacids' pollution sources in eastern Asia. The minor parameters in determining the seasonality at Gosan are meteorological parameters and sink terms.

\subsection{Interannual variability in diacids}

Figure 8 shows year-to-year variations in the major saturated (Fig. 8a-f) and unsaturated (Fig. 8g, h) diacids for April during the time period of 2001-2008. Overall, diacid concentrations are observed to increase from 2001 to 2008 in April. The linear regression analysis, based on the least squares and median and percentile (25th and 75th) concentrations, shows a clear increasing trend with 3.9-47.4\% per year $\left(r^{2}=0.38\right.$ $0.94, p<0.051)$ in April. Significant $(p<0.05)$ enhancements are occasionally observed in other spring and winter months (Table S1); however, the increases are not signifi- 
○ Spring $O$ Summer $\bigcirc$ Fall $\bigcirc$ Winter

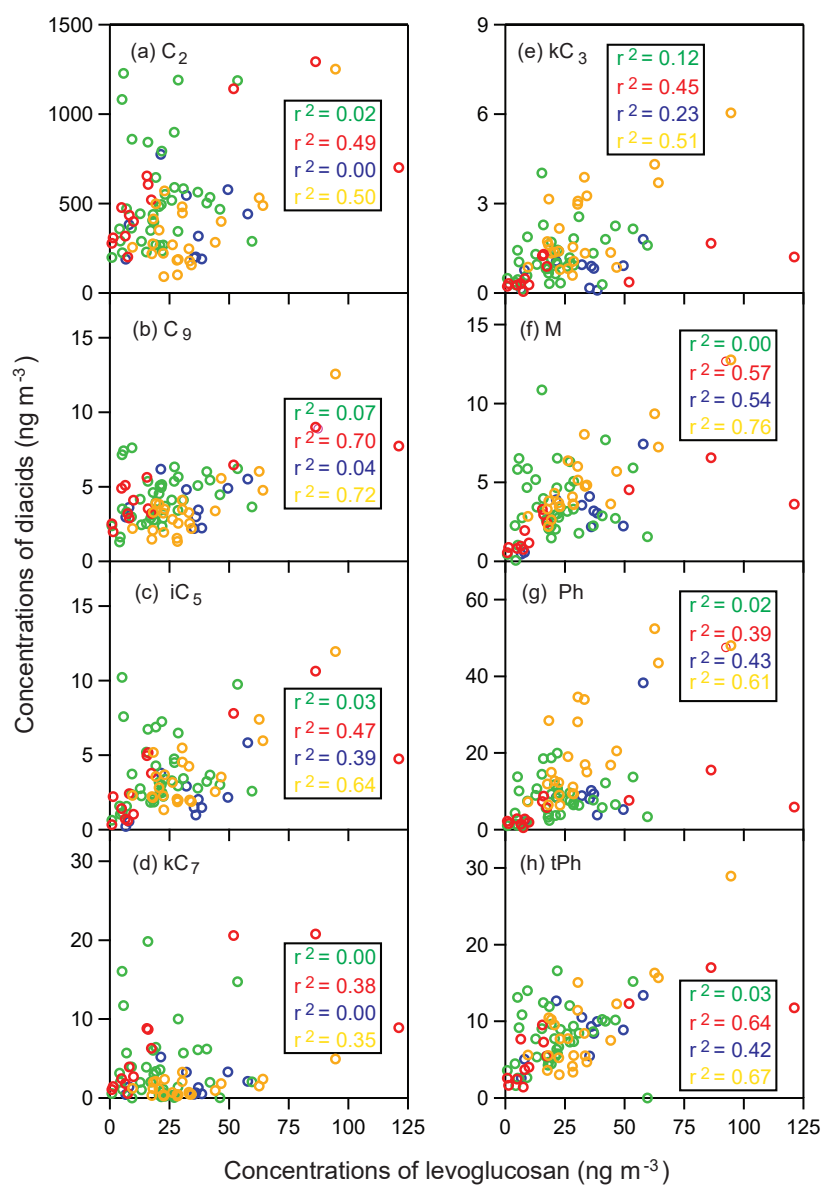

Figure 7. Correlations of levoglucosan (a biomass burning tracer) with saturated (a-e) and unsaturated (f-h) diacids in aerosol samples collected from April 2003 to April 2004: (a) oxalic $\left(\mathrm{C}_{2}\right)$, (b) azelaic $\left(\mathrm{C}_{9}\right)$, (c) methylsuccinic $\left(\mathrm{iC}_{5}\right)$, (d) ketopimelic $\left(\mathrm{kC}_{7}\right)$, (e) ketomalonic $\left(\mathrm{kC}_{3}\right)$, (f) maleic $(\mathrm{M})$, (g) phthalic $(\mathrm{Ph})$ and (h) terephthalic $(\mathrm{tPh})$ acids. Note that data have been grouped according to the season.

cant $(p>0.05)$ in autumn and summer months (Table S1). The interannual variations are interpreted by considering a number of factors, including annual behavior of $\mathrm{CO}, \mathrm{O}_{3}$, VOCs and their oxidation products (glyoxylic acid, glyoxal and methylglyoxal), and biogenic (azelaic acid) and anthropogenic (phthalic acids) tracers. We do not observe any significant variability in air masses during the study period of 2001-2008 (Fig. 3), showing that the variability in air masses does not affect the interannual increases in the diacids.

An increase in CO at Gosan has not been observed in April over the time period of 2001-2008 (Fig. 9a). We also found the absence of correlations between diacids and levoglucosan in April, as discussed above. These results show that direct emissions from combustion sources did not cause the yearly increases in saturated and unsaturated diacids. Instead, atmospheric chemical processes could be responsible for their in-

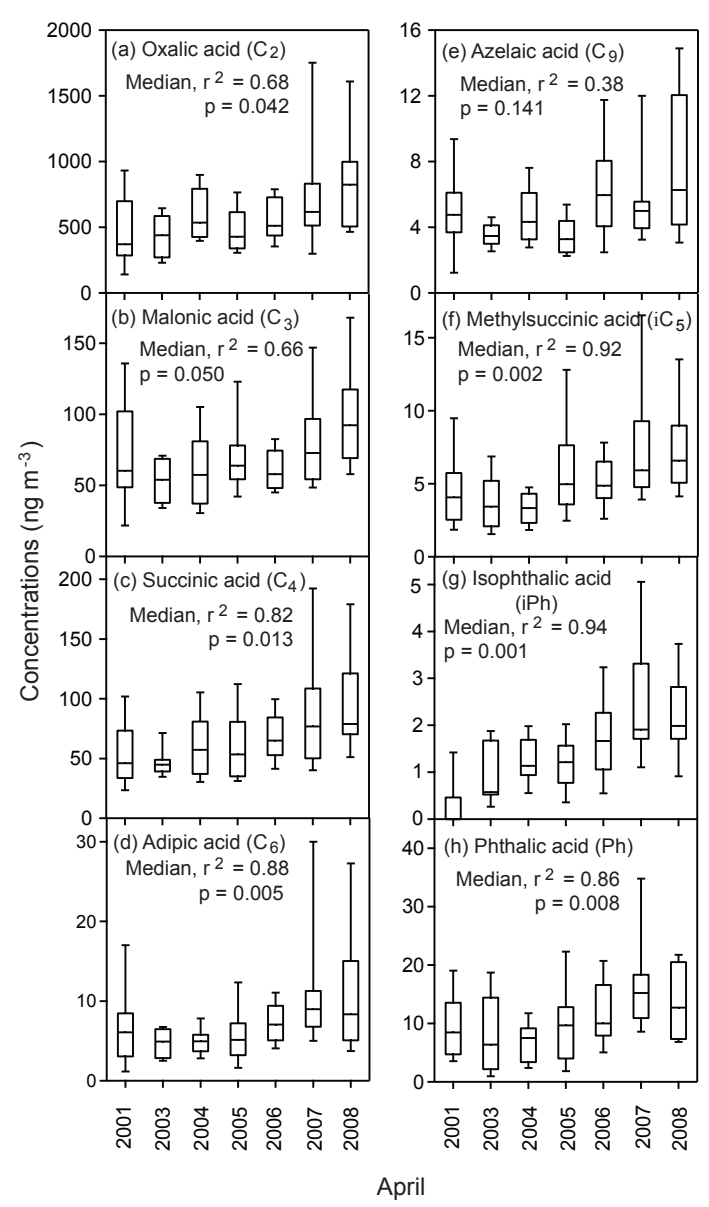

Figure 8. Boxplots depicting the interannual (2001-2008) trends in major saturated $(\mathbf{a}-\mathbf{f})$ and unsaturated $(\mathbf{g}-\mathbf{h})$ diacids in April: (a) oxalic $\left(\mathrm{C}_{2}\right)$, (b) malonic $\left(\mathrm{C}_{3}\right)$, (c) succinic $\left(\mathrm{C}_{4}\right)$, (d) adipic $\left(\mathrm{C}_{6}\right)$, (e) azelaic acid $\left(\mathrm{C}_{9}\right)$, (f) methylsuccinic $\left(\mathrm{iC}_{5}\right),(\mathrm{g})$ isophthalic $(\mathrm{iPh})$, and $(\mathbf{h})$ phthalic $(\mathrm{Ph})$ acids. The trends in interannual variations for the other months are shown in Table S1. The lower, middle, and upper lines in the box represent the 25th, 50th and 75th percentiles, respectively. The lower and upper whiskers represent the 10th and 90th percentiles, respectively. The $r^{2}$ values were calculated based on the median concentrations using a linear regression analysis.

creases in April on a sub-decadal scale. The increases in both $\mathrm{O}_{3}$ and VOCs have been reported at several sites in China, Japan and Korea (Naja and Akimoto, 2004; Ohara et al., 2007; Xu et al., 2008; Wang et al., 2009; Fu and Liao, 2012); this increase may enhance atmospheric chemical processes resulting in the production of diacids in the atmosphere. This explanation can be supported by the increases in glyoxylic acid and glyoxal (Fig. 9b, c), which are the oxidation products of major anthropogenic and biogenic VOCs and intermediates for the production of oxalic acid via aqueous-phase reactions (Myriokefalitakis et al., 2011).

Significant $(p<0.05)$ increases in CO from 2001 to 2008 have been observed in the months of winter (except for February) and autumn (except for October) during the study 


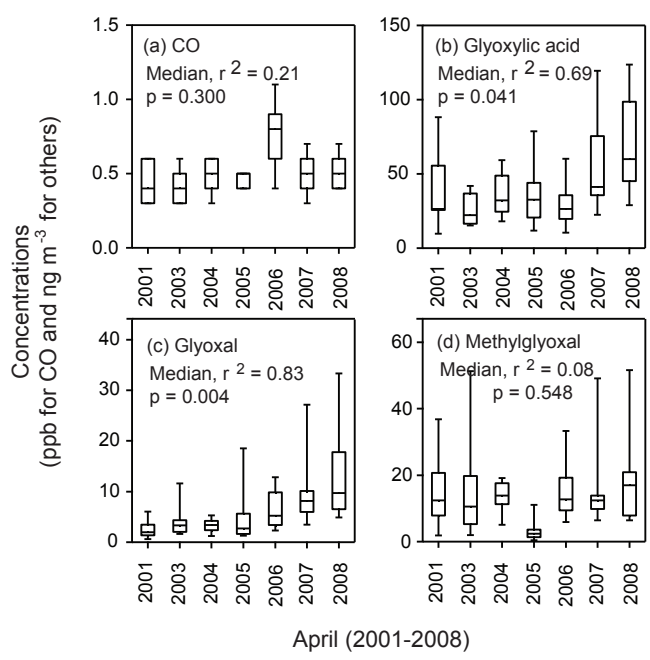

Figure 9. Boxplots depicting interannual (2001-2008) trends in April: (a) carbon monoxide (CO), (b) glyoxylic acid $\left(\omega \mathrm{C}_{2}\right)$, (c) glyoxal (Gly), and (d) methylglyoxal (MGly). The trends in interannual variations for the other months are shown in Table S2. The lower, middle, and upper lines in the box represent the 25th, 50th and 75th percentiles, respectively. The lower and upper whiskers represent the 10th and 90th percentiles, respectively. The $r^{2}$ values were calculated based on the median concentrations using a linear regression analysis.

period (Table S2 in the Supplement); these increases may have been associated with the increases in the emissions of VOCs. However, systematic annual increases in diacids (Table S1) and precursors of oxalic acid (glyoxylic acid, glyoxal and methylglyoxal) (Table S2) were not observed in the months of autumn and winter, suggesting that oxidant concentrations in the cold seasons are not high enough to convert the increased VOCs to diacids. The lack of annual increases in diacids and their precursors in the summer months are indicative of no changes in the emissions of oceanic VOCs and the subsequent chemical processing in the atmosphere.

It is very important to understand whether the atmospheric chemical processing of anthropogenic or biogenic VOCs is causing the increases in the concentrations of diacids in the atmosphere. Phthalic and adipic acids have been reported to form by the oxidation of anthropogenic VOCs (Kalberer et al., 2000; Fisseha et al., 2004), whereas azelaic acid is produced via the oxidation of biogenic unsaturated fatty acids (Kawamura and Gagosian, 1987; Tedetti et al., 2006). We have observed increases in both anthropogenic (phthalic acid and adipic acid) and biogenic (azelaic acid) diacids (Fig. 8), demonstrating that both biogenic and anthropogenic VOCs are causing the April increases in diacids in the atmosphere. Indeed, increases in biogenic and anthropogenic VOCs have been reported in eastern Asia during our study period (Ohara et al., 2007; Fu and Liao, 2012). However, higher yearly increases in anthropogenic diacids than in biogenic diacids (see Fig. 8) are indicative of a greater influ- ence of anthropogenic VOCs in driving the interannual increases in diacids in eastern Asia. The higher influence of anthropogenic VOCs compared to biogenic VOCs can also be evidenced in the lack of correlations between diacids and SOA tracers (2-methyltetrols and pinic acid) in spring as discussed previously. The absence of any increase in methylglyoxal (Fig. 9d), which is an oxidation product of isoprene and $80 \%$ of which has been reported to be generated from the oxidation of isoprene in the atmosphere (Myriokefalitakis et al., 2011), further supports the lesser influence of biogenic VOCs on increased diacids.

\section{Conclusions and atmospheric implications}

The seasonal variations in the pollution sources of diacids, an important fraction of organic aerosols (OAs), remain identical on a sub-decadal scale in eastern Asia. However, the strength of their pollution sources has increased from 2001 to 2008 , which is evidenced by the increase in the loadings of diacids in atmospheric aerosols. The month-specific interannual increases show that this requires not only an enhanced emission of anthropogenic and biogenic VOCs but also their efficient chemical processing. The increases in diacids derived from anthropogenic VOCs are more prominent than those in diacids generated from biogenic VOCs in eastern Asia. The increases in the water-soluble organic acid fraction could modify the aerosol organic composition and its sensitivity to climate relevant physical properties.

Atmospheric pollution control strategies in eastern Asia have successfully decreased the loading of inorganic acidic (sulfate and nitrate) and basic (ammonium) species in recent years (2007-2012) (Boreddy and Kawamura, 2015). However, this study demonstrates that recent pollution control strategies in eastern Asia could not decrease organic acidic species in the atmosphere. The increase in diacids in atmospheric aerosols could still maintain aerosol acidity although inorganic acidic species are decreasing. Aerosol acidity has been shown to increase aerosol yields in the atmosphere (Surratt et al., 2010). Since diacids are water-soluble in nature, their increases will modify the water-uptake activities of atmospheric aerosols, which will have subsequent influences on the direct and indirect climate effects of atmospheric aerosols.

\section{The Supplement related to this article is available online at doi:10.5194/acp-16-585-2016-supplement.}

Acknowledgements. This study was in part supported by the Japan Society for the Promotion of Science (JSPS) through grant-in-aid No. 24221001. The authors acknowledge the NOAA Air Resources Laboratory for the use of the registered version of the HYSPLIT 
model. Shuvashish Kundu is a research fellow supported by the JSPS. The original data related to the paper may be obtained free of charge from the authors.

Edited by: A. Sorooshian

\section{References}

Boreddy, S. K. R. and Kawamura, K.: A 12-year observation of water-soluble ions in TSP aerosols collected at a remote marine location in the western North Pacific: an outflow region of Asian dust, Atmos. Chem. Phys., 15, 6437-6453, doi:10.5194/acp-156437-2015, 2015.

Boucher, O., Randall, D., Artaxo, P., Bretherton, C., Feingold, G., Forster, P., Kerminen, V.-M., Kondo, Y., Liao, H., Lohmann, U., Rasch, P., Satheesh, S. K., Sherwood, S., Stevens, B., and Zhang, X. Y.: Clouds and Aerosols, in: Climate Change 2013: The Physical Science Basis. Contribution of Working Group I to the Fifth Assessment Report of the Intergovernmental Panel on Climate Change, edited by: Stocker, T. F., Qin, D., Plattner, G.-K., Tignor, M., Allen, S. K., Boschung, J., Nauels, A., Xia, Y., Bex, V., and Midgley, P. M., Cambridge University Press, Cambridge, United Kingdom and New York, NY, USA, 595-599, 2013.

Charbouillot, T., Gorini, S., Voyard, G., Parazols, M., Brigante, M., Deguillaume, L., Delort, A.-M., and Mailhot, G.: Mechanism of carboxylic acid photooxidation in atmospheric aqueous phase: Formation, fate and reactivity, Atmos. Environ., 56, 1-8, doi:10.1016/j.atmosenv.2012.03.079, 2012.

Decesari, S., Fuzzi, S., Facchini, M. C., Mircea, M., Emblico, L., Cavalli, F., Maenhaut, W., Chi, X., Schkolnik, G., Falkovich, A., Rudich, Y., Claeys, M., Pashynska, V., Vas, G., Kourtchev, I., Vermeylen, R., Hoffer, A., Andreae, M. O., Tagliavini, E., Moretti, F., and Artaxo, P.: Characterization of the organic composition of aerosols from Rondônia, Brazil, during the LBASMOCC 2002 experiment and its representation through model compounds, Atmos. Chem. Phys., 6, 375-402, doi:10.5194/acp6-375-2006, 2006.

Ding, X., Wang, X.-M., Gao, B., Fu, X.-X., He, Q.-F., Zhao, X.-Y., Yu, J.-Z., and Zheng, M.: Tracer-based estimation of secondary organic carbon in the Pearl River Delta, south China, J. Geophys. Res.-Atmos., 117, D05313, doi:10.1029/2011JD016596, 2012.

Fisseha, R., Dommen, J., Sax, M., Paulsen, D., Kalberer, M., Maurer, R., Höfler, F., Weingartner, E., and Baltensperger, U.: Identification of Organic Acids in Secondary Organic Aerosol and the Corresponding Gas Phase from Chamber Experiments, Anal. Chem., 76, 6535-6540, doi:10.1021/ac048975f, 2004.

Fu, P., Kawamura, K., Chen, J., and Miyazaki, Y.: Secondary Production of Organic Aerosols from Biogenic VOCs over Mt. Fuji, Japan, Environ. Sci. Technol., 48, 8491-8497, doi:10.1021/es500794d, 2014.

$\mathrm{Fu}$, Y. and Liao, H.: Simulation of the interannual variations of biogenic emissions of volatile organic compounds in China: Impacts on tropospheric ozone and secondary organic aerosol, Atmos. Environ., 59, 170-185, doi:10.1016/j.atmosenv.2012.05.053, 2012.

Guenther, A., Karl, T., Harley, P., Wiedinmyer, C., Palmer, P. I., and Geron, C.: Estimates of global terrestrial isoprene emissions using MEGAN (Model of Emissions of Gases and Aerosols from
Nature), Atmos. Chem. Phys., 6, 3181-3210, doi:10.5194/acp-63181-2006, 2006.

Hallquist, M., Wenger, J. C., Baltensperger, U., Rudich, Y., Simpson, D., Claeys, M., Dommen, J., Donahue, N. M., George, C., Goldstein, A. H., Hamilton, J. F., Herrmann, H., Hoffmann, T., Iinuma, Y., Jang, M., Jenkin, M. E., Jimenez, J. L., Kiendler-Scharr, A., Maenhaut, W., McFiggans, G., Mentel, Th. F., Monod, A., Prévôt, A. S. H., Seinfeld, J. H., Surratt, J. D., Szmigielski, R., and Wildt, J.: The formation, properties and impact of secondary organic aerosol: current and emerging issues, Atmos. Chem. Phys., 9, 5155-5236, doi:10.5194/acp-9-51552009, 2009.

Heald, C. L., Henze, D. K., Horowitz, L. W., Feddema, J., Lamarque, J. F., Guenther, A., Hess, P. G., Vitt, F., Seinfeld, J. H., Goldstein, A. H., and Fung, I.: Predicted change in global secondary organic aerosol concentrations in response to future climate, emissions, and land use change, J. Geophys. Res.-Atmos., 113, D05211, doi:10.1029/2007JD009092, 2008.

Hong, J., Häkkinen, S. A. K., Paramonov, M., Äijälä, M., Hakala, J., Nieminen, T., Mikkilä, J., Prisle, N. L., Kulmala, M., Riipinen, I., Bilde, M., Kerminen, V.-M., and Petäjä, T.: Hygroscopicity, CCN and volatility properties of submicron atmospheric aerosol in a boreal forest environment during the summer of 2010, Atmos. Chem. Phys., 14, 4733-4748, doi:10.5194/acp-144733-2014, 2014.

Kalberer, M., Yu, J., Cocker, D. R., Flagan, R. C., and Seinfeld, J. H.: Aerosol Formation in the Cyclohexene-Ozone System, Environ. Sci. Technol., 34, 4894-4901, doi:10.1021/es001180f, 2000.

Kanaya, Y., Cao, R., Akimoto, H., Fukuda, M., Komazaki, Y., Yokouchi, Y., Koike, M., Tanimoto, H., Takegawa, N., and Kondo, Y.: Urban photochemistry in central Tokyo: 1. Observed and modeled $\mathrm{OH}$ and $\mathrm{HO}_{2}$ radical concentrations during the winter and summer of 2004, J. Geophys. Res.-Atmos., 112, D21312, doi:10.1029/2007JD008670, 2007.

Kawamura, K.: Identification of $\mathrm{C}_{2}-\mathrm{C}_{10} \omega$-Oxocarboxylic Acids, Pyruvic Acid, and $\mathrm{C}_{2}-\mathrm{C}_{3}$ Alpha-Dicarbonyls in Wet Precipitation and Aerosol Samples by Capillary GC and GC/MS, Anal. Chem., 65, 3505-3511, doi:10.1021/Ac00071a030, 1993.

Kawamura, K. and Gagosian, R. B.: Implications of $\omega$ Oxocarboxylic Acids in the Remote Marine Atmosphere for Photooxidation of Unsaturated Fatty-Acids, Nature, 325, 330-332, doi:10.1038/325330a0, 1987.

Kawamura, K. and Kaplan, I. R.: Motor Exhaust Emissions as a Primary Source for Dicarboxylic-Acids in LosAngeles Ambient Air, Environ. Sci. Technol., 21, 105-110, doi:10.1021/Es00155a014, 1987.

Kawamura, K. and Sakaguchi, F.: Molecular distributions of water soluble dicarboxylic acids in marine aerosols over the Pacific Ocean including tropics, J. Geophys. Res.-Atmos., 104, 35013509, doi:10.1029/1998JD100041, 1999.

Kawamura, K., Tachibana, E., Okuzawa, K., Aggarwal, S. G., Kanaya, Y., and Wang, Z. F.: High abundances of water-soluble dicarboxylic acids, ketocarboxylic acids and a-dicarbonyls in the mountaintop aerosols over the North China Plain during wheat burning season, Atmos. Chem. Phys., 13, 8285-8302, doi:10.5194/acp-13-8285-2013, 2013.

Kerminen, V.-M., Teinilä, K., Hillamo, R., and Mäkelä, T.: Size-segregated chemistry of particulate dicarboxylic acids 
in the Arctic atmosphere, Atmos. Environ., 33, 2089-2100, doi:10.1016/S1352-2310(98)00350-1, 1999.

Kleindienst, T. E., Jaoui, M., Lewandowski, M., Offenberg, J. H., Lewis, C. W., Bhave, P. V., and Edney, E. O.: Estimates of the contributions of biogenic and anthropogenic hydrocarbons to secondary organic aerosol at a southeastern US location, Atmos. Environ., 41, 8288-8300, doi:10.1016/j.atmosenv.2007.06.045, 2007.

Kundu, S., Kawamura, K., Andreae, T. W., Hoffer, A., and Andreae, M. O.: Molecular distributions of dicarboxylic acids, ketocarboxylic acids and $\alpha$-dicarbonyls in biomass burning aerosols: implications for photochemical production and degradation in smoke layers, Atmos. Chem. Phys., 10, 2209-2225, doi:10.5194/acp-10-2209-2010, 2010a.

Kundu, S., Kawamura, K., and Lee, M.: Seasonal variation of the concentrations of nitrogenous species and their nitrogen isotopic ratios in aerosols at Gosan, Jeju Island: Implications for atmospheric processing and source changes of aerosols, J. Geophys. Res.-Atmos., 115, D20305, doi:10.1029/2009jd013323, 2010 b.

Kundu, S., Kawamura, K., and Lee, M.: Seasonal variations of diacids, ketoacids, and alpha-dicarbonyls in aerosols at Gosan, Jeju Island, South Korea: Implications for sources, formation, and degradation during long-range transport, J. Geophys. Res.Atmos., 115, D19307, doi:10.1029/2010jd013973, 2010c.

Levis, S., Wiedinmyer, C., Bonan, G. B., and Guenther, A.: Simulating biogenic volatile organic compound emissions in the Community Climate System Model, J. Geophys. Res.-Atmos., 108, 4659, doi:10.1029/2002JD003203, 2003.

Liao, H., Chen, W.-T., and Seinfeld, J. H.: Role of climate change in global predictions of future tropospheric ozone and aerosols, J. Geophys. Res.-Atmos., 111, D12304, doi:10.1029/2005JD006852, 2006.

Mochida, M., Kawamura, K., Umemoto, N., Kobayashi, M., Matsunaga, S., Lim, H.-J., Turpin, B. J., Bates, T. S., and Simoneit, B. R. T.: Spatial distributions of oxygenated organic compounds (dicarboxylic acids, fatty acids, and levoglucosan) in marine aerosols over the western Pacific and off the coast of East Asia: Continental outflow of organic aerosols during the ACE-Asia campaign, J. Geophys. Res.-Atmos., 108, 8638, doi:10.1029/2002JD003249, 2003.

Myriokefalitakis, S., Tsigaridis, K., Mihalopoulos, N., Sciare, J., Nenes, A., Kawamura, K., Segers, A., and Kanakidou, M.: Incloud oxalate formation in the global troposphere: a 3-D modeling study, Atmos. Chem. Phys., 11, 5761-5782, doi:10.5194/acp11-5761-2011, 2011.

Naik, V., Delire, C., and Wuebbles, D. J.: Sensitivity of global biogenic isoprenoid emissions to climate variability and atmospheric $\mathrm{CO}_{2}$, J. Geophys. Res.-Atmos., 109, D06301, doi:10.1029/2003JD004236, 2004.

Naja, M. and Akimoto, H.: Contribution of regional pollution and long-range transport to the Asia-Pacific region: Analysis of longterm ozonesonde data over Japan, J. Geophys. Res.-Atmos., 109, D21306, doi:10.1029/2004JD004687, 2004.

Nakicenovic, N., JAlcamo, J., Davis, G., de Vries, B., Fenhann, J., Gaffin, S., Gregory, K., Grübler, A., Jung, T. Y., Kram, T., Rovere, E. L. L., Michaelis, L., Mori, S., Morita, T., Pepper, W., Pitcher, H., Price, L., Riahi, K., Roehrl, A., Rogner, H., Sankovski, A., Schlesinger, Shukla, P., Smith, S., Swart, R., van Rooijen, S., Victor, N., and Dadi, Z.: Emission Scenarios, (Edited by: Nebojsa Nakicenovic and Rob Swart), Cambridge University Press, Cambridge, United Kingdom and New York, NY, USA, 2000.

Nawrot, T. S., Torfs, R., Fierens, F., De Henauw, S., Hoet, P. H., Van Kersschaever, G., De Backer, G., and Nemery, B.: Stronger associations between daily mortality and fine particulate air pollution in summer than in winter: evidence from a heavily polluted region in western Europe, J. Epidemiol. Commun. H., 61, 146149, doi:10.1136/jech.2005.044263, 2007.

Offenberg, J. H., Lewis, C. W., Lewandowski, M., Jaoui, M., Kleindienst, T. E., and Edney, E. O.: Contributions of Toluene and $\alpha$ Pinene to SOA Formed in an Irradiated Toluene/ $\alpha$-Pinene/NOx/ Air Mixture: Comparison of Results Using ${ }^{14} \mathrm{C}$ Content and SOA Organic Tracer Methods, Environ. Sci. Technol., 41, 3972-3976, doi:10.1021/es070089+, 2007.

Ohara, T., Akimoto, H., Kurokawa, J., Horii, N., Yamaji, K., Yan, X., and Hayasaka, T.: An Asian emission inventory of anthropogenic emission sources for the period 1980-2020, Atmos. Chem. Phys., 7, 4419-4444, doi:10.5194/acp-7-4419-2007, 2007.

Richter, A., Burrows, J. P., Nusz, H., Granier, C., and Niemeier, U.: Increase in tropospheric nitrogen dioxide over China observed from space, Nature, 437, 129-132, 2005.

Schauer, J. J., Kleeman, M. J., Cass, G. R., and Simoneit, B. R. T.: Measurement of Emissions from Air Pollution Sources. 1. C1 through C29 Organic Compounds from Meat Charbroiling, Environ. Sci. Technol., 33, 1566-1577, doi:10.1021/es980076j, 1999.

Schauer, J. J., Kleeman, M. J., Cass, G. R., and Simoneit, B. R. T.: Measurement of Emissions from Air Pollution Sources. 3. C1C29 Organic Compounds from Fireplace Combustion of Wood, Environ. Sci. Technol., 35, 1716-1728, doi:10.1021/es001331e, 2001.

Stone, E. A., Hedman, C. J., Zhou, J., Mieritz, M., and Schauer, J. J.: Insights into the nature of secondary organic aerosol in Mexico City during the MILAGRO experiment 2006, Atmos. Environ., 44, 312-319, doi:10.1016/j.atmosenv.2009.10.036, 2010.

Surratt, J. D., Chan, A. W. H., Eddingsaas, N. C., Chan, M., Loza, C. L., Kwan, A. J., Hersey, S. P., Flagan, R. C., Wennberg, P. O., and Seinfeld, J. H.: Reactive intermediates revealed in secondary organic aerosol formation from isoprene, P. Natl. Acad. Sci., 107, 6640-6645, doi:10.1073/pnas.0911114107, 2010.

Swietlicki, E., Hansson, H. C., Hämeri, K., Svenningsson, B. Massling, A., McFiggans, G., McMurry, P. H., Petäjä, T., Tunved, P., Gysel, M., Topping, D., Weingartner, E., Baltensperger, U., Rissler, J., Wiedensohler, A., and Kulmala, M.: Hygroscopic properties of submicrometer atmospheric aerosol particles measured with H-TDMA instruments in various environments - a review, Tellus B, 60, 432-469, doi:10.1111/j.16000889.2008.00350.x, 2008.

Tao, Z. and Jain, A. K.: Modeling of global biogenic emissions for key indirect greenhouse gases and their response to atmospheric $\mathrm{CO}_{2}$ increases and changes in land cover and climate, J. Geophys. Res.-Atmos., 110, D21309, doi:10.1029/2005JD005874, 2005.

Tedetti, M., Kawamura, K., Charriere, B., Chevalier, N., and Sempere, R.: Determination of low molecular weight dicarboxylic and ketocarboxylic acids in seawater samples, Anal. Chem., 78, 6012-6018, doi:10.1021/Ac052226w, 2006. 
Tedetti, M., Kawamura, K., Narukawa, M., Joux, F., Charrière, B., and Sempéré, R.: Hydroxyl radical-induced photochemical formation of dicarboxylic acids from unsaturated fatty acid (oleic acid) in aqueous solution, J. Photoch. Photobio. A, 188, 135139, doi:10.1016/j.jphotochem.2006.11.029, 2007.

Tsigaridis, K. and Kanakidou, M.: Secondary organic aerosol importance in the future atmosphere, Atmos. Environ., 41, 46824692, doi:10.1016/j.atmosenv.2007.03.045, 2007.

Wang, T., Wei, X. L., Ding, A. J., Poon, C. N., Lam, K. S., Li, Y. S., Chan, L. Y., and Anson, M.: Increasing surface ozone concentrations in the background atmosphere of Southern China, 19942007, Atmos. Chem. Phys., 9, 6217-6227, doi:10.5194/acp-96217-2009, 2009.

Warneck, P.: In-cloud chemistry opens pathway to the formation of oxalic acid in the marine atmosphere, Atmos. Environ., 37, 2423-2427, doi:10.1016/S1352-2310(03)00136-5, 2003.
Xu, X., Lin, W., Wang, T., Yan, P., Tang, J., Meng, Z., and Wang, Y.: Long-term trend of surface ozone at a regional background station in eastern China 1991-2006: enhanced variability, Atmos. Chem. Phys., 8, 2595-2607, doi:10.5194/acp-8-2595-2008, 2008.

Zhang, Q., Jimenez, J. L., Canagaratna, M. R., Allan, J. D., Coe, H., Ulbrich, I., Alfarra, M. R., Takami, A., Middlebrook, A. M., Sun, Y. L., Dzepina, K., Dunlea, E., Docherty, K., DeCarlo, P. F., Salcedo, D., Onasch, T., Jayne, J. T., Miyoshi, T., Shimono, A., Hatakeyama, S., Takegawa, N., Kondo, Y., Schneider, J., Drewnick, F., Borrmann, S., Weimer, S., Demerjian, K., Williams, P., Bower, K., Bahreini, R., Cottrell, L., Griffin, R. J., Rautiainen, J., Sun, J. Y., Zhang, Y. M., and Worsnop, D. R.: Ubiquity and dominance of oxygenated species in organic aerosols in anthropogenically-influenced Northern Hemisphere midlatitudes, Geophys. Res. Lett., 34, L13801, doi:10.1029/2007g1029979, 2007. 